\title{
Conservation assessment and action on Lotus sanguineus (Fabaceae), a critically endangered endemic species to Turkey
}

\author{
Ümit Subaşı ${ }^{1 * *}$ ๑ , Fatoş Şekerciler ${ }^{2} \&$ Mecit Vural $\left.\right|^{3}$
}

Key words: Conservation action, IUCN assessment, Lotus sanguineus (Vural) D. D. Sokoloff, Endemic, Turkey.

Ključne besede: varstvene akcije, IUCN ocena, Lotus sanguineus (Vural) D. D. Sokoloff, endemit, Turčija.

Received: 31. 12. 2019

Revision received: 20.3. 2020

Accepted: 20. 3. 2020

\begin{abstract}
Lotus sanguineus is one of the endemic taxa from Mediterranean Region of Turkey. It has hitherto been known from type locality and was assessed under VU and EN categories despite the lack of information on the population size, number of location and habitat quality. This study aims to determine the global conservation status and conservation strategies of the narrow endemic species. We collected all available data and evaluated them with the field studies. We reported the sizes of populations, altitude, coordinates, habitat types and the threats it faces for each locality. GeoCAT analyses at global levels indicate the extent of occurrence $19.965 \mathrm{~km}^{2}$ and area of occupancy $9 \mathrm{~km}^{2}$ and there could be an inferred decline due to habitat loss and fragmentation of the original population, suggesting this species might be classified as Critically Endangered, based on criterium B1ab (i, ii, iii) + $2 \mathrm{ab}$ ( $\mathrm{i}$, ii, iii) in the Red List categorization. Conservation priorities include life history and ecology studies, in-situ conservation, population monitoring and ex-situ conservation to prevent the destruction of the existing gene pool.
\end{abstract}

\begin{abstract}
Izvleček
Lotus sanguineus je ena izmed endemitskih vrst mediteranske regije v Turčiji. Dosedaj je poznana samo $s$ tipske lokalitete in je uvrščena v kategoriji VU in EN, kljub pomanjkanju informacij o velikosti populacije, številu lokalitet in kakovosti habitata. V članku želimo ugotoviti globalni naravovarstveni status vrste in ohranitvene strategije za to ozko endemično vrsto. Zbrali smo vse razpoložljive podatke in jih ovrednotili s terenskimi raziskavami. Poročamo o velikosti populacij, nadmorski višini, habitatnem tipu in grožnjah za vsako lokacijo. $Z$ analizo GeoCAT na globalnem nivoju smo ugotovili obseg pojavljanja na $19,965 \mathrm{~km}^{2}$ in območje zasedenosti $9 \mathrm{~km}^{2}$. Pričakujemo lahko upad populacije zaradi izgube habitatov in razdrobljenosti prvotne populacije, zato lahko vrsto po kategorizaciji Rdečega seznama ocenimo kot Kritično ogroženo (CE) na osnovi kriterija B1ab (i, ii, iii) + 2ab (i, ii, iii). Naravovarstvene prioritete vključujejo raziskave življenjske zgodovine in ekologije, in-situ varovanje, populacijski monitoring in ex-situ varovanje za preprečevanje uničenja obstoječega genskega nabora.
\end{abstract}

\footnotetext{
1 Ege University Faculty of Sciences, Department of Biology, 35100, İzmir, Turkey. E-mail: subasi_umit@hotmail.com

2 Ankara University, Faculty of Sciences, Department of Biology, 06100, Tandoğan, Ankara Turkey.

3 Gazi University, Faculty of Sciences, Department of Biology, Ankara, Turkey.

* Corresponding author
} 


\section{Introduction}

Turkey has a rich biodiversity and endemism rate resulting from its geographical location, geological and geomorphological features, influence of different climates, range of soil types, topographical diversity with marked changes in ecological factors over a short distance (Vural et al. 1999). All these factors contribute to its biological uniqueness. It is home to 11707 plant taxa and approximately one in every three plants (3649 endemic taxa) in Turkey is endemic (Güner et al. 2012). This floristic and habitat richness of the country makes it important for global conservation, but has long been neglected in terms of conservation efforts and faces severe challenges. Particularly the effects of agro-pastoral human societies such as overgrazing, illegal cuttings, population growth, the increase of cereal farming and unplanned urbanization have led the large-scale destruction of important habitat for many species in Anatolia.

Assessment of the conservation status of threatened species has become necessary in the present world to prevent the extinction of that species due to the rapid degradation of the natural ecosystems with the increase of human populations (Akman et al. 2014). Determination of the threat, i.e., the extent of the threat and/or the expectation of survival of a threatened species is an important tool to conserve biodiversity (Bernardos et al. 2006). In this context, The IUCN Red List is globally recognized as a standard not only serving to highlight extinction risk levels of species, but also providing guidance to species conservation responses, identifying priority.

Dorycnium sanguineum Vural firstly described by Vural (1983) is basionym of Lotus sanguineus (Vural) D. D. Sokoloff, one of the endemic taxa only known from the Karaman province in Turkey. Since the early 19th century, most European authors accepted Lotus and Dorycnium as two closely related, but distinct Fabaceae genera (Taubert 1894; Rikli 1901; Dominguez \& Galiano 1979; Talavera \& Salgueiro 1999). However, according to recent molecular phylogenetic studies, accepted by many authors suggested that it should not be separated from Lotus (Allan et al. 2003, 2004; Degtjareva et al. 2006, 2008; Sandral et al. 2010). In this article contrary to tradition, authors prefer to accept former members of Dorycnium placement in Lotus genus as accepted on the International Plant Names Index (IPNI) (https:// www.ipni.org/n/77067709-1).

Lotus sanguineus has a very limited distribution but its habitat characteristics, limit of its distribution, locations, population size, and potential threats of the populations are not sufficiently well known. According to Red Data Book of Turkish Plants (Ekim et al. 2000), the threat category of the species is VU (Vulnerable). On the other hand, Kocabaş (2014) proposes the category EN (Endangered) for $L$. sanguineus, only with an estimation of its distribution area. This study aims to determine the extinction risk of this rare endemic species on a global scale and its conservation strategies in consideration of the urgency of deficiencies in conservation. For this purpose, the distribution, population size, habitat characteristics of the $L$. sanguineus and threats on the species are identified, and therefore the conservation actions are proposed.

\section{Methods}

All the existing information relevant to the systematics and distribution of Lotus sanguineus has been evaluated (Davis et al. 1988; Vural 1983). Collected specimens deposited in herbarium ANK have been examined whereas the samples deposited in Royal Botanic Garden Edinburgh (E) herbarium have been accessed on online type specimen catalogues (JSTOR Global Plants, http:// plants.jstor.org/). The seed samples have been deposited with their genbank numbers (GKN: 045232) in the Seed Gene Bank - Republic of Turkey Ministry of Agriculture and Forestry General Directorate of Agricultural Research and Policies.

The single known locality of $L$. sanguineus from where herbarium specimens were recorded has been confirmed by field works, and then, surveyed to determine the distribution of the species during May-August 2016.

For all localities, coordinates, population size (number of the individuals), elevation, habitat type (following the IUCN habitats classification scheme ver 3.1. (IUCN 2012a)), and the threats (following the IUCN threats classification scheme ver 3.2. (IUCN 2012b)) were recorded. Also, the species that accompanying with Lotus sanguineus were collected and identified. All coordinates were determined by using the Global Positioning System (GPS). Habitat and threat types of each locality were obtained from field observations. The numbers of individuals were estimated by sampling 10 quadrats randomly from each locality, the quadrat sizes were $5 \times 5 \mathrm{~m}$ (Guidi 2010). The numbers of individuals were estimated using the following formula:

$$
N_{S}=\sum_{i=1}^{n}\left(\frac{\mu_{i}}{25}\right) s_{i}
$$

Wherein, Ns is the number of individuals of a species, $\mu \mathrm{i}$ is the mean number of individuals in locality $i$, and $S i$ is the total area of locality $\mathrm{i} ; \mu \mathrm{i} / 25$ is the density per $\mathrm{m}^{2}$ (Guidi 2010). Calculation of the EOO (Extent of Occur- 
rence) and $\mathrm{AOO}$ (Area of Occupancy) was carried out by using Geo-Cat (Bachman et al. 2011; http://geocat.kew. org/). Because of the narrow distributions of the species and the details on spatial information, which are available in the Area of Occupancy, by using a grid of $1 \mathrm{~km}^{2}$ has been calculated. A $1 \mathrm{~km}^{2}$ grid can be used for assessment when high precision data are available (IUCN 2011). Area of Occupancy (AOO, $\left.\mathrm{km}^{2}\right)$, Extent of Occurrence $\left(\mathrm{EOO}, \mathrm{km}^{2}\right)$, population numbers and field observations were used to reassess the conservation status of this species applying the IUCN (2012c) Categories and Criteria (ver 3.1).

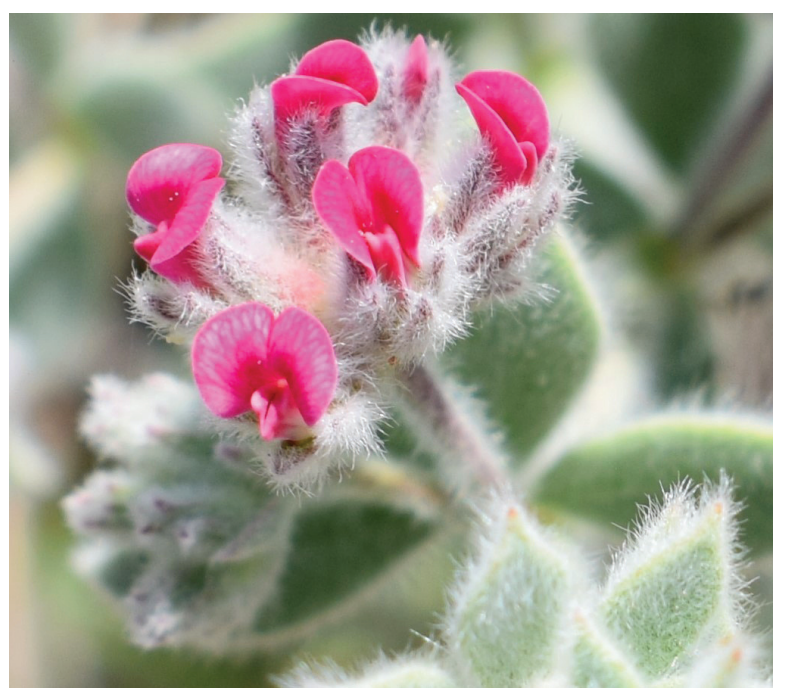

\section{Results}

\section{Taxonomy}

Lotus sanguineus (Vural) D. D. Sokoloff, Byull. Moskovsk. Obshch. Isp. Prir., Otd. Biol. 108(3): 43 (2003).

Basionym: Dorycnium sanguineum Vural Notes Roy. Bot. Gard. Edinburgh 41(1): 69 (1983). Type: Turkey C4 Konya: Karaman, Bucakkisla, east slopes of Cevlik Da., in open Pinus brutia forest, calcareous substrate, 550 m, 29 vi 1981, M. Vural 1976 (holo. ANK; iso. E, G, Selcuk Unv. Konya). (http://130.241.157.62/ pdfs/DOC070804b.pdf; https://plants.jstor.org/ search?filter=name\&so=ps_group_by_genus_species+as $c \&$ Query=Dorycnium+sanguineum)

Subcaespitose perennial herbaceous plants, woody at base. Stem up to $20-40 \mathrm{~cm}$, soft, white-villous hairy. Leaves with 5-leaflets, rachis $1-4 \mathrm{~mm}$ long; leaflets 5-20 $\times 3-10 \mathrm{~mm}$, oblong-obovate to oblong, both sides densely villous, mucronate at apex, old leaflets sometimes nearly violent. Inflorescence umbellate 4-8-flowered. Peduncles $0.5-2 \mathrm{~cm}$ long; involucral bracts are equal to the number of flowers, lanceolate, $2.5-4 \mathrm{~mm}$ long, green. Flowers sessile or subsessile, pedicels up to $1 \mathrm{~mm}$. Calyx \pm curved, slightly gibbose at base, $5 \mathrm{~mm}$ long, white-hairy, lobes narrowly triangular-lanceolate, slightly longer than calyx tube, purple at apex; stramineus tube, pale-red.

Figure 1: General appearance of Lotus sanguineus in Kölese location. Slika 1: Vrsta Lotus sanguineus na lokaciji Kölese.

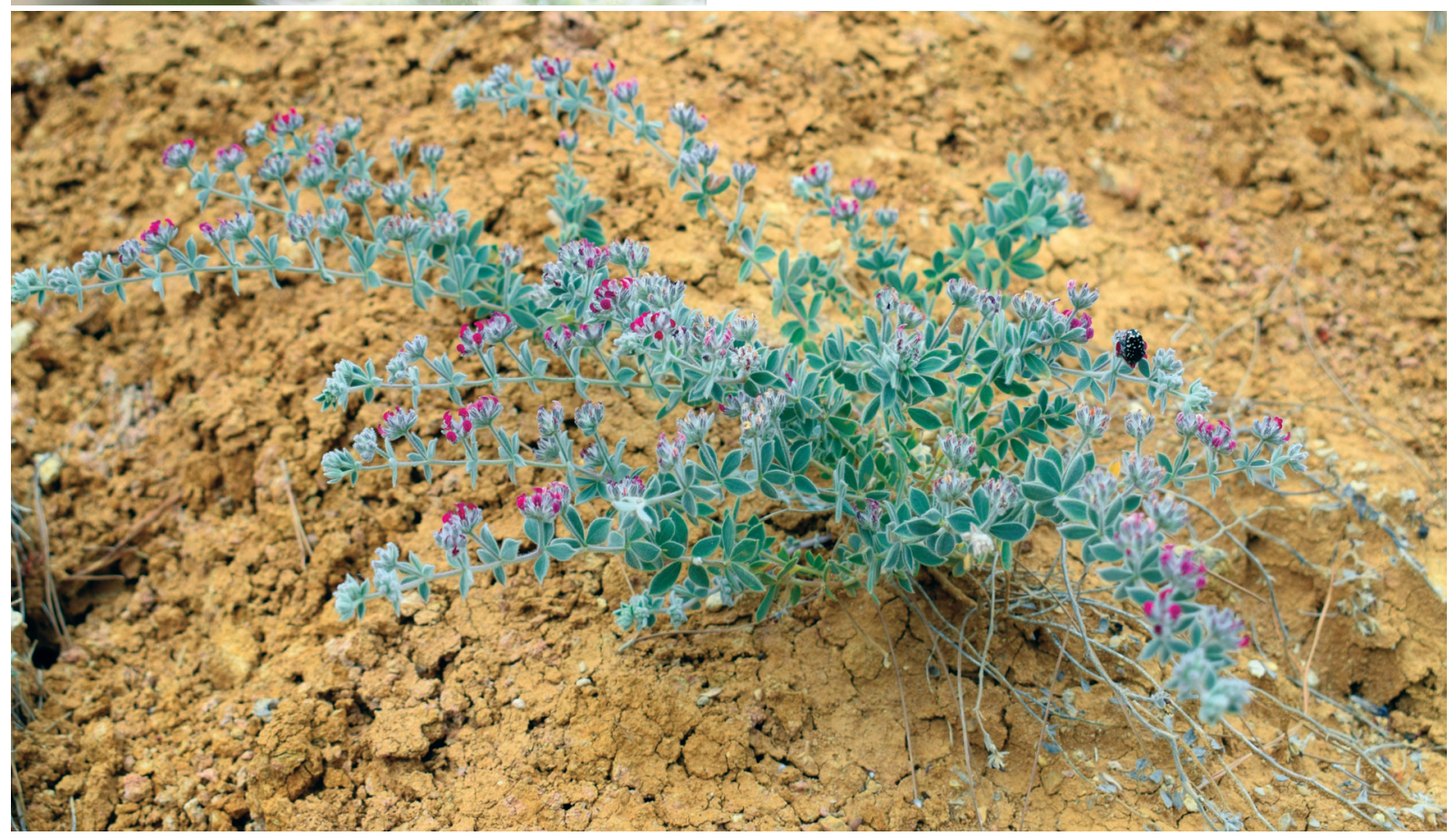


Corolla bright sanguineus; vexillum 5-7 mm; limbs deflected $90^{\circ}$, wings $5 \mathrm{~mm}$ and coherent at apex, keel $4 \mathrm{~mm}$ long. Ovarium 8-13 ovuled, 2-2.5 mm long, dense villosum. Legume $5 \times 3 \mathrm{~mm}$ (excluding long beak $1.5 \mathrm{~mm}$ ), ovoid, densely hirsute except base, valves reticulato-rugosae, not contorting at maturity. Seeds $1-2,2.5-3 \mathrm{~mm}$ long, smooth, green.

Etymology: The species epithet comes from its sanguineous (blood-red) corolla colour.

Recognition: L. sanguineus is easily distinguished from Turkish allies with blood-red coloured flowers and densely white shiny hairs covering the whole stem (Figure 1)

Distribution, habitat and ecology: The type locality of Lotus sanguineus was confirmed in the current paper. It was known only from its type locality since 1983 (Vural 1983) whereas we recently identified 5 (at Kurucabel, Kölese, Çukur, Aşağıakın villages) new localities (Figure 2-3, Table 1) near Bucakkışla in Karaman. The area of localities range from $90,624 \mathrm{~m}^{2}$ to $1,051,651 \mathrm{~m}^{2}$. The area in which $L$. sanguineus was discovered occupies the most
Southern part of Central Anatolia by constituting a set of compact limestone and marly limestones in Karaman (Turkey). Located at the transition zone of the Central Taurus Mountains and the Central Anatolian caused rich biodiversity in terms of both Irano-Turanian and Mediterranean floristic elements. Hence, forest, maquis and steppe communities belonging to both Mediterranean and Central Anatolian vegetation occupied the region. According to the field observations the Mediterranean elements are common in the habitats of the L. sanguineus because these areas are located on the south-facing slopes of the relatively hot and lower parts of the valley. This area is in the C4 square in the grid scheme of Davis and is in the Eastern Mediterranean floristic region phytogeographically. Göksu River formed two valleys in this mountainous terrain, one of them passes through Bucakkışla in the north where species identified for the first time.

The dominant bioclimate is characterized as a semi-arid Mediterranean climate experienced by hot and dry summers followed by cold and wet winters. The mean an-

Table 1: The six sites where Lotus sanguineus has been located, with altitude range, habitats classification scheme coded (IUCN 2012a) and identified threats (IUCN 2012b).

Tabela 1: Šest lokacij, kjer smo našli vrsto Lotus sanguineus, njihov višinski razpon, oznaka habitata (IUCN 2012a) in potencialne grožnje (IUCN 2012b).

\begin{tabular}{|c|c|c|c|c|c|c|}
\hline \begin{tabular}{|l|} 
Locality \\
No.
\end{tabular} & Locality & \begin{tabular}{|l|} 
Estimated \\
Population \\
Size
\end{tabular} & $\begin{array}{l}\text { Area of sites } \\
\left(\mathrm{m}^{2}\right)\end{array}$ & $\begin{array}{l}\text { Elevation } \\
\text { ( } \mathrm{m} \text { above } \\
\text { sea level) }\end{array}$ & $\begin{array}{l}\text { Habitat (IUCN habitats } \\
\text { classification scheme) }\end{array}$ & $\begin{array}{l}\text { Assessed threats (IUCN threat } \\
\text { classification scheme) }\end{array}$ \\
\hline 1 & $\begin{array}{l}\text { Çukur Köyü } 1 \\
\text { (ÇK1) }\end{array}$ & 580 & 90,624 & $710-770$ & $\begin{array}{l}\text { 14.1 Arable land } \\
\text { 14.3 Plantations open Pinus } \\
\text { brutia forest, calcareous } \\
\text { substrate, Pistachio orchards }\end{array}$ & $\begin{array}{l}\text { 2.1 Annual \& Perennial Non-Timber Crops; } \\
\text { 2.1.2 Small-holder Farming. } \\
\text { 2.3 Livestock Farming \& Ranching; } \\
\text { 4.1 Roads \& Railroads }\end{array}$ \\
\hline 2 & $\begin{array}{l}\text { Çukur Köyü } 2 \\
\text { (ÇK2) }\end{array}$ & 2,334 & 291,702 & $650-780$ & $\begin{array}{l}\text { 14.3 Plantations open Pinus } \\
\text { brutia forest, calcareous } \\
\text { substrate, Pistachio orchards } \\
\text { 14.2 Pastureland }\end{array}$ & $\begin{array}{l}\text { 2.1 Annual \& Perennial Non-Timber Crops; } \\
\text { 2.1.2 Small-holder Farming. } \\
\text { 2.3 Livestock Farming \& Ranching; } \\
\text { 4.1 Roads \& Railroads }\end{array}$ \\
\hline 3 & $\begin{array}{l}\text { Aşağıakın Köyü } \\
\text { (AK) }\end{array}$ & 6,731 & $1,051,651$ & $750-900$ & $\begin{array}{l}\text { 14.2 Pastureland } \\
\text { Pinus brutia forest, } \\
\text { calcareous substrate }\end{array}$ & $\begin{array}{l}\text { 2.1 Annual \& Perennial Non-Timber Crops; } \\
\text { 2.1.2 Small-holder Farming. } \\
\text { 2.3 Livestock Farming \& Ranching; } \\
\text { 2.3.2 Small-holder Grazing, Ranching } \\
\text { or Farming } \\
\text { 4.1 Roads \& Railroads }\end{array}$ \\
\hline 4 & $\begin{array}{l}\text { Kölese Mevki } \\
(\mathrm{KM})\end{array}$ & 5,007 & 782,287 & $520-570$ & $\begin{array}{l}\text { 14.1 Arable land } \\
\text { 14.3 Plantations open Pinus } \\
\text { brutia forest, calcareous } \\
\text { substrate, Pistachio orchards }\end{array}$ & $\begin{array}{l}\text { 2.1 Annual \& Perennial Non-Timber Crops; } \\
\text { 2.1.2 Small-holder Farming. } \\
\text { 2.3 Livestock Farming \& Ranching; } \\
\text { 4.1 Roads \& Railroads }\end{array}$ \\
\hline 5 & \begin{tabular}{l|} 
Kurucabel \\
(Bucakkışla, BK)
\end{tabular} & 5,937 & 618,394 & 510-700 & $\begin{array}{l}\text { 14.1 Arable land } \\
\text { 14.3 Plantations open Pinus } \\
\text { brutia forest, calcareous } \\
\text { substrate, Pistachio orchards } \\
\text { 14.2 Pastureland }\end{array}$ & $\begin{array}{l}\text { 2.1 Annual \& Perennial Non-Timber Crops; } \\
\text { 2.1.2 Small-holder Farming. } \\
\text { 2.3 Livestock Farming \& Ranching; } \\
\text { 4.1 Roads \& Railroads }\end{array}$ \\
\hline 6 & $\begin{array}{l}\text { Kurucabel } 2 \\
(\mathrm{~KB})\end{array}$ & 6,356 & 794,525 & $350-450$ & $\begin{array}{l}\text { 14.1 Arable land } \\
\text { 14.3 Plantations open Pinus } \\
\text { brutia forest, calcareous } \\
\text { substrate, Pistachio orchards } \\
\text { 14.2 Pastureland } \\
\end{array}$ & $\begin{array}{l}\text { 2.1 Annual \& Perennial Non-Timber Crops; } \\
\text { 2.1.2 Small-holder Farming. } \\
\text { 2.3 Livestock Farming \& Ranching; } \\
\text { 4.1 Roads \& Railroads }\end{array}$ \\
\hline Total & & 26,945 & $3,629.183$ & & & \\
\hline
\end{tabular}




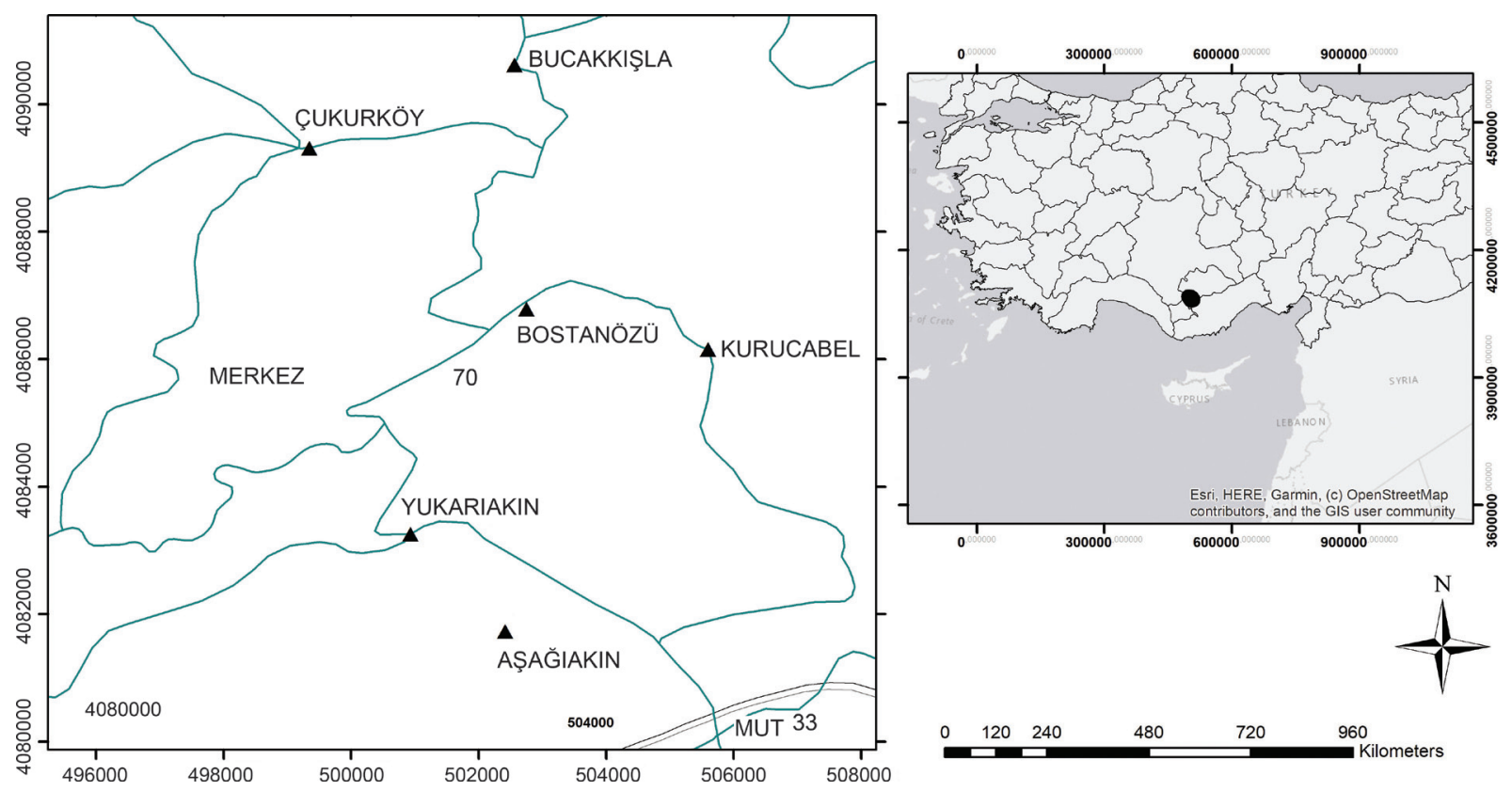

Figure 2: Distribution of Lotus sanguineus.

nual average temperature is $19.2^{\circ} \mathrm{C}$ and precipitation is $597.3 \mathrm{~mm}$. It can be seen that heavy rainfall is received in November to April, while the dry period extends from the beginning of May until the end of October. The most of precipitation occurs in the spring and winter (https:// www.mgm.gov.tr/).

Lotus sanguineus is an Eastern Mediterranean element prefering open calcareous habitats that are represented by open Pinus brutia Ten. forests and Pistacia terebinthus L., Quercus coccifera L. and Quercus infectoria Oliv. maquis, which are characteristic of Mediterranean vegetation. The species is also found on roadsides, gardens, and field borders that are formed as result of anthropogenic effects. Agricultural activities, various orchards (especially pistachios, Pistachio orchards) and extensive herbicide use are the common threats on the population of the taxon. In addition, opening new agricultural fields, and activities for road repairing and widening are such threats creating risk of destroying the habitat of this species (Table 1). Dense goat grazing pressure is observed in particular, at Aşağıakın Village locality; the individuals of the species were more stunted in the grazed parts.

The species is distributed between elevations of 350 900 m east, north, northeast slopes of Çevlik Mountain in the Karaman, along southern part of the Göksu river on rocky substrates rich in limestone. It grows on the red Mediterranean and brown forest (rendzina) soils of forest openings. It is a member of the highly specialized sclerophyllous oak and conifer forest communities of the alliance Quercion calliprini Zohary 1955 (Quercetalia cal-
Slika 2: Razširjenost vrste Lotus sanguineus.

liprini Zohary 1955 order of Quercetea ilicis Br.-Bl. ex A. Bolos et O. de Bol os in A. Bolos y Vayreda 1950) and in several localities it forms ecotone zone of the CentaureoPinetum brutiae Vural et al. 1999 forest association. The associated species of the association are Pinus brutia L., Centaurea pinetorum Hub.-Mor. (End), Astragalus roseocalycinus V. A. Matthews (End), Peucedanum chryseum (Boiss. \& Heldr.) D. F. Chamb. (End), Pistacia terebinthus L., Crataegus azarolus L., Arbutus andrachne L., Quercus coccifera L., Quercus infectoria Oliv., Styrax officinalis L., Gonocytisus angulatus Spach, Juniperus oxycedrus L. Thymbra capitata (L.) Cav., Olea europaea L., Cerastium fragillimum Boiss., Fumana arabica (L.) Spach. (Vural et al. 1999). Main accompanying plants of the L. sanguineus are Pistacia terebinthus L., Pistacia vera L., Thymus revulutus Celak., Stachys cretica L., Sideritis bilgerana P. H. Davis, Scorpiurus subvillosus L., Asteriscus aquaticus (L.) Less, Dianthus zonatus Fenzl., Helianthemum nuтmularium (L.) Mill, Thymbra spicata subsp. spicata, Tripodion tetraphyllum (L.) Fourr.

Recommended threatened category: The current total estimated population size is calculated here to be 26,945 individuals: 580 in Çukur Köyü1(ÇK1), 2,334 in Çukur Köyü2 (ÇK2), 6,731 in the Aşağıakın Köyü (AK), 5,007 in Kölese Mevki (KM), 5,937 in Kurucabel (Bucakkışla, $\mathrm{BK}$ ) and 6,356 in Kurucabel 2 (KB); the estimated population size of each locality ranges between 580 and 6,350 individuals.

GeoCAT analyses at global level calculate EOO values (extent of occurrence) $19.965 \mathrm{~km}^{2}$ and AOO (area of oc- 


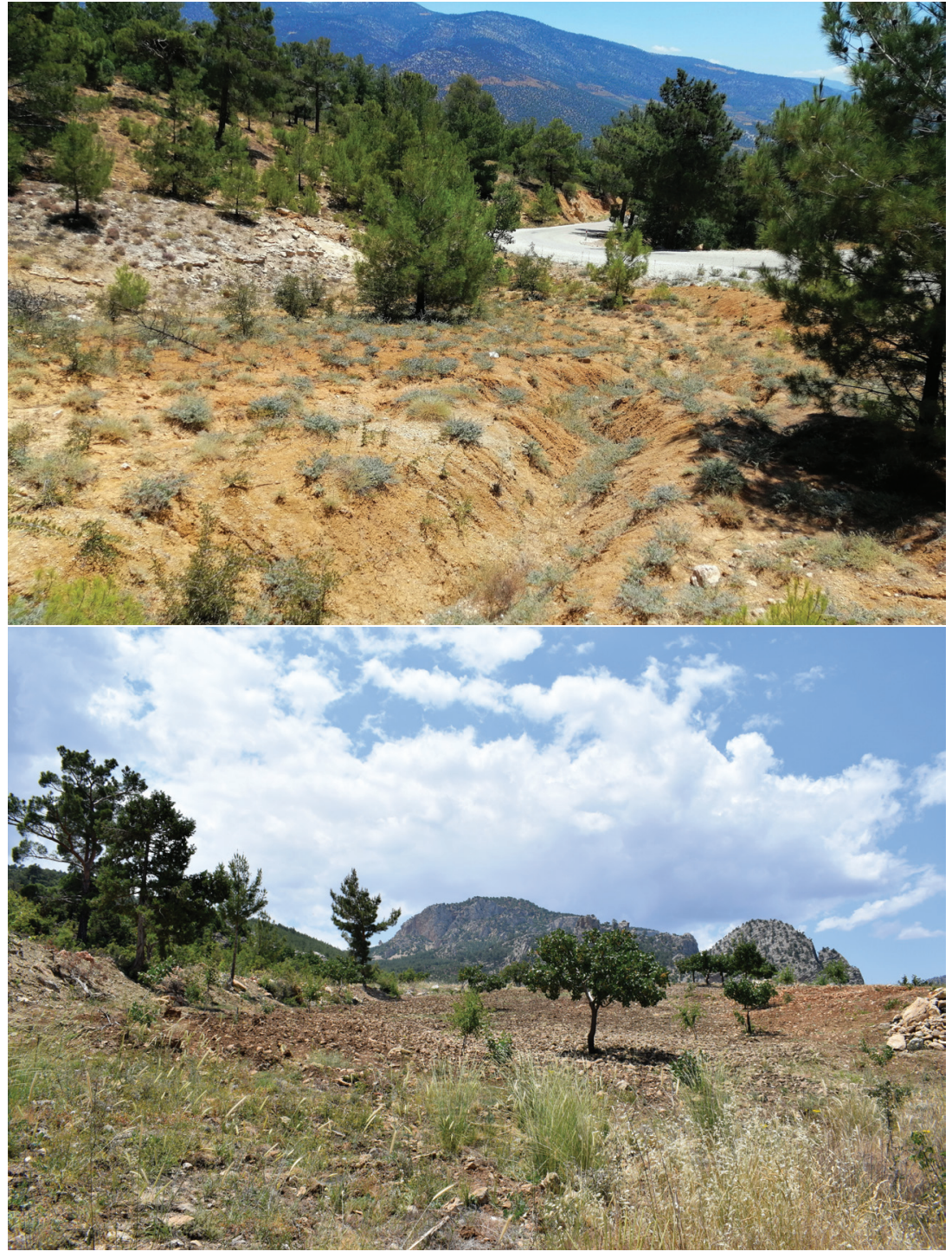

Figure 3: Habitats of Lotus sanguineus. Locality on open Pinus brutia forests and roadside in Kurucabel (above), locality on Pistachio orchards in Cukur village (above).

Slika 3: Rastišča vrste Lotus sanguineus. Lokacija v odprtem gozdu vrste Pinus brutia in na cestnem robu pri naselju Kurucabel (zgoraj), lokacija v nasadu pistacij pri vasi Çukur (spodaj). cupancy) values $9 \mathrm{~km}^{2}$, and that there is an inferred decline due to habitat loss and fragmentation of the original population suggesting that this species might be classified as Critically Endangered; we obtained the Red List categorization of Critically Endangered for Lotus sanguineus, based on criterium B1ab (i, ii, iii) + 2ab (i, ii, iii).

\section{Discussion}

Habitat loss and fragmentation due to agricultural activities (crop fields and orchards) are the greatest threats to the entire population of Lotus sanguineus. Grazing (goats) and such activities to be conducted on roads also create risk of destroying the habitat and individuals of the species. Nevertheless, the effects of grazing on the population are not fully known. Some studies show that overgrazing causes a decrease in plant biomass, reduced plant cover, contributes to the change of plant communities with declined plant height, and threatens vegetation and endemic plants (Campbell and Donlan 2005; Gizicki 2016). On the other hand, some researches indicate that even heavy grazing does not reduce pasture productivity and does not lead to deterioration of grass community structure (Olsvig-Whittaker et al. 2006). In our study, it was observed that Lotus sanguineus individuals were shorter and more glaucous gray in Așağıakın Village (AK) locality where grazing pressure was found.

When habitats of a rare and/or endemic species are damaged and/or degraded by mismanagement and other variuos human activities, species' distribution areas, population sizes, and genetic variability will be reduced, and 
the members thereof will become vulnerable to extinction more extensively than other species (Işı1k 2011). Fragmentation of habitats may also cause an indirect adverse impact on plants due to the fact that pollinators or seed dispersers may have difficulty in finding their host plants (Mullu 2016). The knowledge of the reproductive biology of Lotus sanguineus is still incomplete. However, it is known that Lotus spectabile, other species of the genus, exhibits high levels of self-incompatibility (Calero and Santos 1988), and is pollinated by insects (Hyrnenoptera and Lepidoptera), and their seeds may be dispersed by gravity (Bouza et al. 2002; Mesa Coello et al. 2013). Dorycnium hirsutum Ser. (Jakobsson et.al. 2008) and Lotus herbaceus (Vill.) Jauzein, (Basionym: Dorycnium herbaceum Vill.) (Kozuharova 2000) are also considered among such plant species frequently visited by insects. In consideration of the distance between determined localities (12 km furthest distance) of Lotus sanguineus, and the properties of its plausible pollinators (if it was accepted as an entomophilous plant that based on close relatives), it is not possible to say that there is no gene flow between the localities. However, the increased fragmentation due to continuing heavy agricultural activities in the distribution area were highlighted to be a plausible threat for this species, suggesting difficulty with gene transfer among subpopulations, which might contribute to population fragmentation. It was suggested that agricultural activities causing habitat fragmentation and loss are major threats to Mediterranean ecosystems. Studies on Lamyropsis microcephala (Moris) Dittrich \& Greuter (Fenu et al. 2011) and Tulipa cypria Stapf (Trias-Blasi et al. 2016), which are rare plant species of the Mediterranean region, also recorded similar threats.

The current global population size of Lotus sanguineus is estimated to be 26,945; and expected to decrease in the number of individuals as well as the number of localities due to habitat losses. While the smallest population size was found in Çukur Village, the highest population size was calculated in Așağıakın village (Table 1). The geographic range of $L$. sanguineus calculated by GeoCAT as EOO (extent of occurrence) and AOO (area of occupancy) has been measured as $19.965 \mathrm{~km}^{2}$ and $9 \mathrm{~km}^{2}$, respectively. According to IUCN (2019), the current status of the species can be evaluated as CR (Critically Endangered) based on the $\mathrm{B}$ criterium in terms of $\mathrm{EOO}$ value $<100 \mathrm{~km}^{2}\left(19.965 \mathrm{~km}^{2}\right) \mathrm{B} 1 \mathrm{~b}$ (i, ii), AOO (area of occupancy) value $<10 \mathrm{~km}^{2}\left(9 \mathrm{~km}^{2}\right) \mathrm{B} 2 \mathrm{~b}$ (i, ii). However, Section 4.11 in the IUCN guidelines (IUCN 2019) suggests that "The term 'location' defines a geographically or ecologically distinct area in which a single threatening event can rapidly affect all individuals of the taxon present". All subpopulations of the taxon were considered a single location due to the presence of a single major threat in the habitats (condition (a) under Criterion B1 and B2). Besides, continuing decline area, extent, and quality of the habitat fulfill condition (iii) under Criterion B1b and B2b. As result of all these evaluations, we evaluated the global conservation status of Critically Endangered (CR) for Lotus sanguineus, based on the new IUCN Red List criteria (IUCN, 2019), Blab (i, ii, iii) + 2ab (i, ii, iii).

Table 2: Conservation actions needed and research needed proposed and carried out, for L. sanguineus. Conservation actions coded following IUCN (2012b) and research needed coded according to IUCN (2012d).

Tabela 2: Predlagane in izvedene varstvene akcije in raziskave, potrebne za ohranjenje vrste Lotus sanguineus. Varstvene akcije so v skladu z IUCN (2012b), potrebne raziskave pa z IUCN (2012d).

\begin{tabular}{|c|c|c|c|}
\hline $\begin{array}{c}\text { Conservation } \\
\text { action }\end{array}$ & \multicolumn{1}{|c|}{ Proposed } & $\begin{array}{c}\text { Research } \\
\text { needed }\end{array}$ & Adopted \\
\hline $\begin{array}{c}\text { 3. Species } \\
\text { manage- } \\
\text { ment }\end{array}$ & $\begin{array}{c}3.4 \text { Ex-situ } \\
\text { conservation }\end{array}$ & 1 Research & $\begin{array}{r}1.2 \text { Population } \\
\text { size, distribu- } \\
\text { tion \& trends }\end{array}$ \\
\hline $\begin{array}{c}\text { 4. Education } \\
\text { and } \\
\text { cawareness }\end{array}$ & $\begin{array}{c}\text { 4.2 Training } \\
4.3 \text { Awareness \& } \\
\text { communications }\end{array}$ & & $\begin{array}{c}1.3 \text { Life history } \\
\text { and ecology }\end{array}$ \\
\hline
\end{tabular}

IUCN Red List proposes necessary conservation measures and studies for Lotus sanguineus (Table 2). To establish a long-term conservation action for $L$. sanguineus, it is necesssary to complete the missing data on the life history and ecology of the species as a priority. Understanding the reproductive biology (reproductive success, pollination, seed germination, and seedling, etc) of the taxon besides genetic structure of the population is important. However, as such studies require long-term researches, we propose an integrated conservation plan for L. sanguineus through in-situ conservation, population monitoring, and ex-situ conservation in order to prevent the destruction of the existing gene pool. Local farmers and managers could work with the government for limiting the cultivated areas (especially pistachio orchards), or preventing habitat loss and fragmentation by restricting the opening of new crop fields and road renewal - expansion works, grazing pressure within the distribution area in the future. Besides, the renaturalization of farmlands could create a new habitat for the reintroduction of the species. Establishing cooperation between research institutes and local management authorities is strongly needed for long term monitoring of population size, distribution, trend, grazing under control and plan public education, and awareness for the conservation of Lotus sanguineus. 


\section{Acknowledgement}

This research project was supported by the Republic of Turkey General Directorate of Nature Conservation and National Parks of the Ministry of Agriculture and Forestry. We offer our thanks to Yılmaz Katı and Nurçin Ünlü for editing the manuscript.

\section{Ümit Subaşi ID, https://orcid.org/0000-0002-8003-6227}

\section{References}

Akman, Y., Ketenoğlu, O., Kurt, L. \& Vural, M. 2014: İç Anadolu step vejetasyonu [The steppe vegetation of Central Anatolia]. Palme Yayıncilik, Ankara, TR, $351 \mathrm{pp}$.

Allan, G. J., Francisco-Ortega, J., Santos-Guerra, A., Boerner, E. \& Zimmer, E. A. 2004: Molecular phylogenetic evidence for the geographic origin and classification of Canary Island Lotus (Fabaceae: Loteae). Molecular Phylogenetics and Evolution 32: 123-138.

Allan, G. J., Zimmer, E. A., Wagner, W.L. \& Sokoloff, D. D. 2003: Molecular phylogenetic analyses of tribe Loteae (Leguminosae): Implications for classification and biogeography. In: Klitgaard, B. B. \& Bruneau, A. (eds.), Advances in legume systematics, vol. 10. Kew: Royal Botanic Gardens, Kew, pp. 371-393.

Bachman, S., Moat, J., Hill, A. W., de la Torre, J. \& Scott, B. 2011: Supporting Red List threat assessments with GeoCAT: Geospatial conservation assessment tool. ZooKeys 150: 117-126.

Bernardos, S., Amado, A. \& Amich, F. 2006: The narrow endemic Scrophularia valdesii Ortega-Olivencia \& Devesa (Scrophulariaceae) in the Iberian Peninsula: an evaluation of its conservation status. Biodiversity Conservation 15: 4027-4043.

Bouza, N., Caujapé-Castells, J., González-Pérez, M. A., Batista, F. \& Sosa, P. A. 2002: Population structure and genetic diversity of two endangered endemic species of the Canarian Laurel Forest: Dorycnium spectabile (Fabaceae) and Isoplexis chalcantha. (Scrophulariaceae). International Journal of Plant Sciences 163(4): 619-630.

Calero, A. \& Santos, A. 1988: Biología reproductiva de especies amenazadas en la Flora Canaria. Lagascalia 15(suppl): 661-666.

Campbell, K. \& Donlan, C. J. 2005: Feral goat eradications on islands. Conservation Biology 19: 1362-1374.

Collar, N. J. 1996: The reasons for Red Data Books. Oryx 30: $121-130$.

Davis, P. H., Mill, R. R. \& Tan, K. 1988: Flora of Turkey and the East Aegean Islands, vol. 10. Edinburgh(UK): Edinburgh University Press.

Degtjareva, G. V., Kramina, T. E., Sokoloff, D. D., Samigullin, T. H., Valiejo-Roman, C. M. \& Antonov, A. S. 2006: Phylogeny of the genus Lotus (Leguminosae, Loteae): Evidence from nrITS sequences and morphology. Canadian Journal of Botany 84: 813-830.

Degtjareva, G. V., Kramina, T. E., Sokoloff, D. D., Samigullin, T. H., Sandral, G. \& Valiejo-Roman, C. M. 2008: New data on nrITS phylogeny of Lotus (Leguminosae, Loteae). Wulfenia 15: 35-49
Dominguez, E. \& Galiano, E. F. 1979: Revision del genero Tetragonolobus Scop. (Fabaceae). Lagascalia 8: 189-214.

Ekim, T., Koyuncu, M., Vural, M., Duman, H., Aytaç, Z. \& Adıgüzel, N. 2000: Türkiye Bitkileri Kırmızı Kitabı (Eğrelti ve Tohumlu Bitkiler). Ankara (TR): Publications of Association of Turkey's Nature Conservation.

Fenu, G., Mattana, E. \& Bacchetta, G. 2011: Distribution, status and conservation of a Critically Endangered, extremely narrow endemic: Lamyropsis microcephala (Asteraceae) in Sardinia. Oryx 45(2): 180-186.

Gizicki, S. Z. 2016: Effects of invasive goats (Capra hircus) on Mediterranean Island Communities [master's thesis]. Michigan (US): University of Michigan.

Guidi, T. 2010: Le piante endemiche dell'Arcipelago Toscano. Valutazione della vulnerabilità [The endemic plants of the Tuscan Archipelago. Vulnerability assessment] [dissertation]. Ubaldo Montelatici (ITL): Università degli Studi di Firenze.

Güner, A., Aslan, S., Ekim, T., Vural, M. \& Babaç, M. T. 2012: Türkiye Bitkileri Listesi (Damarlı Bitkiler). Nezahat Gökyiğit Botanik Bahçesi ve Flora Araştırmaları Derneği Yayını. İstanbul, 1290 pp.

Işık, K. 2011: Rare and endemic species: why are they prone to extinction? Turkish Journal of Botany 35: 411-417.

IUCN. 2001: IUCN Red List Categories and Criteria: version 3.1. IUCN Species Survival Commision. IUCN, Gland, Switzerland and Cambridge (UK).

IUCN. 2012a: Habitats classification scheme (Version 3.1); [accessed 2019 Aug 08]. https://www.iucnredlist.org/resources/habitatclassification-scheme.

IUCN. 2012b: Threats classification scheme (Version 3.2.); [accessed 2018 Dec 15]. http://www.iucnredlist.org/documents/Dec_2012 Guidance_Threats_Classification_Scheme.pdf..

IUCN. 2012c: IUCN Red List Categories and Criteria: version 3.1. Second Edition, Gland, Switzerland and Cambridge (UK).

IUCN. 2012d: Research needed classification scheme v.2.0.; [accessed 2016 Apr 07]. http://www.iucnredlist.org/technical-documents/ classification-schemes/research-needed-classification-scheme-ver2.

IUCN. 2019: Guidelines for using the IUCN red list categories and criteria (Version 14). Prepared by the Standards and Petitions Subcommittee; [accessed 2019 Jul 09]. https://www.iucnredlist.org/ resources/redlistguidelines.

Jakobsson, A., Padro'n, B. \& Traveset, A. 2008: Pollen transfer from invasive Carpobrotus spp. to natives - A study of pollinator behaviour and reproduction success. Biological Conservation 141: 136-145.

Kocabaş, Y. Z. 2014: Türkiye'deki Dorycnıum Mıller. (Fabaceae) cinsinin revizyonu [Revision of the genus Dorycnium Miller. (Fabaceae) in Turkey] [dissertation]. Kahramanmaraş (TR): Kahramanmaraş Sütçü İmam Üniversitesi.

Kozuharova, E.K. 2000: Entomophilous plant species inhabiting the southern limestone slopes of Mt. Vitosha (SW Bulgaria) and their pollinators. Flora Mediterranea 10: 227-234.

Mesa Coello, R., Ojeda Land, E. \& Rodríguez Núñez, S. 2013: Dorycnium spectabile. The IUCN Red List of Threatened Species 2013: e.T162282A5568420. [accessed 2019 Sep 12]. http://dx.doi. org/10.2305/IUCN.UK.2011-1.RLTS.T162282A5568420.en. 
Mullu, D. 2016: A Review on the effect of habitat fragmentation on ecosystem. Journal of Natural Sciences Research 6(15): 2224-3186.

Olsvig-Whittaker, L., Frankenberg, E., Perevolotsky, A. \& Ungar, D. E. 2006: Grazing, overgrazing and conservation: Changing concepts and practices in the Negev rangelands. Sécheresse 17(1-2): 195-199.

Rikli, M. 1901: Die Gattung Dorycnium Mill. - Botanische Jahrbücher für Systematik, Pflanzengeschichte und Pflanzengeographie 31: 314-404.

Sandral, G., Degtjareva, G. V., Kramina, T.E., Sokoloff, D. D., Samigullin, T. H., Hughes, S. \& Valiejo-Roman, C. M. 2010: Are Lotus creticus and Lotus cytisoides (Leguminosae) closely related species? Evidence from nuclear ribosomal ITS sequence data. Genetic Resources and Crop Evolution 57: 501-514.

Talavera, S. \& Salgueiro, F.J. 1999: Sobre el tratamiento de la familia Leguminosae en Flora Iberica. Lagascalia 21: 155-122.

Taubert, P. H.W. 1894: Leguminosae. In: Engler, A. \& Prantl, K. (eds.), Die natürlichen Pflanzenfamilien, 3(3). Leipzig: Engelmann, pp. $70-385$.

Trias-Blasi, A., Gücel, S. \& Özden, Ö. 2016: Current distribution and conservation status reassessment of the Cyprus Tulip (Tulipa cypria: Liliaceae), new data from Northern Cyprus. Plant Biosystem 151(3): $394-402$.

Vural, M. 1983: New taxa and records from Turkey (Dorycnium sanguineum Vural) in Notes R.G.B. Edinburgh 41(1): 67-69.

Vural, M., Akman, Y. \& Quezel, P. 1999: Contribution a L'etude De La Vegetation Forestiere Du Taurus Central: Analyse Phyto-Ecologique D'un Transect Sud-Nord, Entre Silifke et Karaman. Fitosociologia 36(1): 3-21 